\title{
Kajian Daya Dukung Air di Pulau Bintan, Provinsi Kepulauan Riau
}

\author{
Dian Hudawan Santoso \\ Jurusan Teknik Lingkungan, Fakultas Teknologi Mineral, Universitas Pembangunan Nasional "Veteran" Yogyakarta \\ Email: hudageo@gmail.com
}

\begin{abstract}
Abstrak
Daya dukung air merupakan kemampuan sumberdaya air untuk memenuhi suatu kebutuhan dengan meninjau besarnya ketersediaan air. Daya dukung air dihitung berdasarkan perhitungan kebutuhan air dan ketersediaan air. Kedua variabel tersebut dibandingkan sehingga dapat diketahui air yang tersedia dapat mencukupi untuk berbagai kebutuhan. Kajian daya dukung air Pulau Bintan dilakukan guna mengetahui potensi kebutuhan dan ketersediaan air sehingga dengan mengetahui hal tersebut kemudian dapat digunakan untuk analisis dan evaluasi terhadap perencanaan wilayah dan tata ruang Pulau Bintan. Berdasarkan hasil kajian diketahui bahwa kebutuhan air Pulau Bintan secara keseluruhan mencapai 67.726.595 m3/th di mana kebutuhan terbesar dari sektor perikanan. Sedangkan ketersediaan air Pulau Bintan mencapai 2.431.819.623 m3/th dan setelah dibandingkan dengan luas pulau diperoleh ketersediaan air sebesar 11.704,55 m3/th/km2. Berdasarkan ketersediaan dan kebutuhan airnya, maka Pulau Bintan mengalami surplus sumberdaya air karena besarnya ketersediaan jauh lebih banyak daripada kebutuhan.
\end{abstract}

Kata Kunci : sumberdaya air, daya dukung, ketersediaan air, kebutuhan air

\section{PENDAHULUAN}

Pulau Bintan merupakan pulau terbesar di Propinsi Kepulauan Riau yang terdiri atas hampir 3000 pulau besar dan kecil terbagi menjadi 2 wilayah administrasi, yaitu Kota Tanjung Pinang dan Kabupaten Bintan. Dengan letak geografis yang strategis (antara Laut Cina selatan, selat Malaka dengan selat Karimata) serta didukung potensi alam yang sangat potensial, Pulau Bintan dimungkinkan untuk menjadi salah satu pusat pertumbuhan ekonomi bagi Negara Republik Indonesia dimasa depan.

Pada saat ini telah terjadi ketidak seimbangan antara ketersediaan air dengan kebutuhan air di lapangan. Ketersediaan air terus menurun sementara permintaan air terus meningkat. Berdasarkan undang-undang tentang Sumberdaya Air, untuk menangani ketidakseimbangan air antara ketersediaan air dan kebutuhan air harus dikelola dengan baik dengan mempertimbangkan fungsi lingkungan sosial dan ekonomi (Haryanto, 2013)

Penentuan daya dukung khususnya daya dukung air suatu wilayah merupakan salah satu pendekatan dalam evaluasi pemanfaatan ruang wilayah. Pulau Bintan merupakan pulau di wilayah Provinsi Kepulauan Riau yang memiliki berbagai potensi sumber daya alam untuk menopang pembangunan daerah khususnya bagi daerah Kabupaten Bintan dan Kota Tanjung Pinang yang berada di Pulau ini. Seiring berjalannya waktu, berbagai sektor aktivitas manusia mulai tumbuh dan 
berkembang dengan pesat di Pulau Bintan, meliputi perdagangan antar pulau, pariwisata, penambangan, permukiman dan industri pendukung Pulau Batam. Aktivitas pembangunan tersebut secara langsung maupun tidak langsung dapat menyebabkan terjadinya penurunan daya dukung wilayah khususnya daya dukung air di Pulau Bintan pada masa akan datang yang sulit untuk dihindari. Menurunya potensi ketersediaan dan kualitas air menjadikan kondisi yang perlu dikhawatirkan di masa mendatang. Dampak lain yang mungkin akan muncul seperti terjadinya kerusakan dan pencemaran lingkungan, bencana alam dan konflik sosial yang dapat mengancam kehidupan manusia dan makhluk hidup lainnya di Pulau Bintan.

Memperhatikan hal tersebut, serta menghindari terjadinya penurunan atau "overshoot" potensi ketersediaan dan penurunan kualtas air, maka perlu dilakukan kajian daya dukung air Pulau Bintan untuk dapat menjadi dasar bagi perencanaan pemanfaatan sumber daya alam dan tata ruang di Pulau Bintan. Adapun tujuan dari penelitian ini adalah mengetahui seberapa besar kemampuan daya dukung air yang berupa potensi ketersediaan dan kebutuhan air di Pulau Bintan dalam mendukung kehidupan manusia dan kegiatan pembangunan lainnya.

Dengan dilakukan penelitian ini maka diharapkan hasil kajian dapat dijadikan acuan atau pedoman dalam pemanfaatan sumber daya alam dan perencanaan tata ruang di Pulau Bintan, sehingga dapat mencegah "overshoot" atau terlampauinya daya dukung air dan wilayah Pulau Bintan.

\section{METODE PENELITIAN}

Daya dukung air merupakan kemampuan sumberdaya air untuk memenuhi suatu kebutuhan dengan meninjau besarnya ketersediaan air. Daya dukung air dihitung berdasarkan perhitungan kebutuhan air dan ketersediaan air. Kedua variabel tersebut dibandingkan sehingga dapat diketahui air yang tersedia dapat mencukupi untuk berbagai kebutuhan.

Variabel yang Digunakan :

- Ketersediaan air $\left(\mathrm{m}^{3} / \mathrm{th}\right)$

- Luas wilayah $\left(\mathrm{km}^{2}\right)$

- Kebutuhan air total $\left(\mathrm{m}^{3} / \mathrm{th}\right)$

- Jumlah penduduk (jiwa)

Daya dukung air diperhitungkan berdasarkan besarnya ketersediaan air dan kebutuhan air. Hal ini dapat dijelaskan sebagai berikut: 


\section{Ketersediaan Air}

Ketersediaan air di suatu DAS berupa air permukaan dan airtanah dalam angka rata-rata tahunan, menurut Notodihardjo (1982), jumlah air yang tersedia di daratan sebesar 25\% sampai 35\% dari curah hujan dikurangi evapotranspirasi. Air yang tersedia ini disebut aliran mantap yaitu aliran yang tersedia setiap waktu pada rata-rata tahunan. Ketersediaan air dapat dihitung dengan pendekatan neraca air secara meteorologis.

$$
\mathbf{P}=\mathbf{R o}+\mathbf{E t} \pm \Delta \mathbf{S t}
$$

Keterangan :

$\mathrm{P} \quad=$ Curah hujan rata-rata tahunan $(\mathrm{mm} / \mathrm{th})$

$\mathrm{Et}=$ Evapotranspirasi rata-rata tahunan $(\mathrm{mm} / \mathrm{th})$

Ro = Aliran rata-rata tahunan $(\mathrm{mm} / \mathrm{th})$

$\Delta \mathrm{St}=$ Perubahan simpanan (lengas tanah, airtanah dan air genangan) air dalam DAS

(Seyhan, 1977)

Bila neraca air tersebut diterapkan untuk perhitungan rata-rata jangka panjang, maka perubahan simpanan air dalam DAS dapat dianggap nol, sehingga air yang tersedia menjadi :

Total ketersediaan air $\quad($ Ro $)=\mathbf{P}-\mathbf{E t}$

dan jumlah air yang dapat diandalkan sebesar 25\% sampai 35\% dari Ro.

Evapotranspirasi aktual (Et) dihitung dengan metode Turc-Langbein (Keijne, 1973) sebagai berikut :

$$
\begin{aligned}
& \mathrm{Et}=\frac{\mathrm{P}}{\sqrt{\left(0,9+\left(\mathrm{P}^{2} / \mathbf{E o}^{2}\right)\right)}} \\
& \mathrm{Eo}=325+21 \mathrm{~T}+\mathbf{0 , 9} \mathrm{T}^{2}
\end{aligned}
$$

Keterangan :

Et $=$ evapotranspirasi aktual $(\mathrm{mm} / \mathrm{th})$

$\mathrm{P}=$ curah hujan rata-rata DAS $(\mathrm{mm} / \mathrm{th})$

$\mathrm{T}=$ suhu udara rata-rata tahunan $\left({ }^{\circ}\right.$ Celcius $)$

Eo $=$ evaporasi permukaan air bebas $(\mathrm{mm} / \mathrm{th})$ 
Nilai T (suhu udara) dapat ditentukan berdasarkan suhu rata-rata tahunan dari stasiun yang sudah diketahui. Penentuan suhu udara stasiun lainnya berdasar perhitungan dengan menggunakan rumus Mock (1973) sebagai berikut :

$$
\mathbf{t}_{1}=\mathbf{t}_{2} \pm\left(\mathbf{h}_{1}-\mathbf{h}_{2}\right) 0,006{ }^{\circ} \mathrm{C}
$$

Keterangan :

$\mathrm{t}_{1} \quad=$ suhu udara stasiun yang dicari $\left({ }^{\circ} \mathrm{C}\right)$

$\mathrm{t}_{2}=$ suhu udara stasiun yang diketahui $\left({ }^{\circ} \mathrm{C}\right)$

$\mathrm{h}_{1} \quad$ = tinggi tempat stasiun yang dicari $(\mathrm{m})$

$\mathrm{h}_{2} \quad$ = tinggi tempat stasiun yang diketahui $(\mathrm{m})$

$0,006=$ gradien temperatur yang menunjukkan setiap kenaikan $100 \mathrm{~m}$ tinggi tempat maka temperaturnya turun $0,6^{\circ} \mathrm{C}$.

Ketersediaan air DAS yang mantap $(\mathrm{Ya}) \quad=(\mathbf{P}-\mathbf{E t}) \times 30 \% \times \mathbf{A})\left(\mathrm{m}^{3} / \mathbf{t h} / \mathbf{k m}^{2}\right)$

\section{Kebutuhan Air}

Kebutuhan air dasar untuk manusia (Za) didekati dengan kebutuhan air total seluruh DAS dibagi dengan jumlah penduduk DAS

$$
\mathbf{Z a}=\frac{\mathbf{Q d o m}+\mathbf{Q i d}+\mathbf{Q t}+\mathbf{Q f p}+\mathbf{Q i}}{\mathbf{P}}
$$

Keterangan :

$\mathrm{Za}=$ kebutuhan air dasar manusia $\left(\mathrm{m}^{3} / \mathrm{th} /\right.$ kapita $)$

Qdom = kebutuhan air domestik $\left(\mathrm{m}^{3} / \mathrm{th}\right)$

Qid = kebutuhan air untuk industri $\left(\mathrm{m}^{3} / \mathrm{th}\right)$

Qt = kebutuhan air untuk ternak $\left(\mathrm{m}^{3} / \mathrm{th}\right)$

Qfp = kebutuhan air untuk perikanan $\left(\mathrm{m}^{3} / \mathrm{th}\right)$

Qi = kebutuhan air untuk irigasi $\left(\mathrm{m}^{3} / \mathrm{th}\right)$

$\mathrm{P} \quad=$ jumlah penduduk DAS (jiwa)

\section{Daya Dukung Air (DDA)}

Berdasarkan ketersediaan air mantap di dalam DAS dan kebutuhan air dasar manusia, maka dapat dirumuskan daya dukung air: (Soewarno, 2000)

$$
\text { DDA = Ya/Za }\left(\text { kapita } / \mathbf{k m}^{2}\right)
$$

Keterangan : 


$$
\begin{aligned}
& \text { DDA }=\text { daya dukung air }\left(\text { kapita } / \mathrm{km}^{2}\right) \\
& \mathrm{Ya}=\text { ketersediaan air di dalam DAS }\left(\mathrm{m}^{3} / \mathrm{th} / \mathrm{km}^{2}\right) \\
& \mathrm{Za}=\text { kebutuhan air dasar untuk manusia }\left(\mathrm{m}^{3} / \mathrm{th} / \text { kapita }\right)
\end{aligned}
$$

\section{HASIL DAN PEMBAHASAN}

Pulau Bintan secara administratif terdiri atas Kabupaten Bintan dan Kotamadya Tanjung Pinang sebagai ibu kota Provinsi Kepulauan Riau. Penelitian mengenai daya dukung air dirasakan perlu untuk mengetahui apakah sumberdaya air di Pulau Bintan mengalami defisit atau bahkan surplus. Perhitungan daya dukung air ini meliputi analisis kebutuhan dan ketersediaan air.

Hasil perhitungan menunjukkkan kecamatan-kecamatan yang berada di Pulau Bintan kebutuhan airnya bervariasi. Wilayah yang mempunyai kebutuhan air paling besar yaitu Kecamatan Bukit Bestari sebesar $4.264 .295 \mathrm{~m}^{3} /$ th sedangkan kebutuhan air terkecil adalah Kecamatan Mantang sebesar 79.015 m³/th. Secara keseluruhan Pulau Bintan kebutuhan air domestiknya termasuk dalam tiga kategori yaitu rendah yang banyak ditemui di daerah perdesaan dan sedang maupun tinggi yang dijumpai di daerah kota khususnya Kota Tanjungpinang. Adapun jumlah kebutuhan air domestik untuk Pulau Bintan yaitu 13.340.093 m³/th untuk Kota Tanjungpinang (daerah urban) dan 2.686.626 $\mathrm{m}^{3} / \mathrm{th}$ untuk Kabupaten Bintan (daerah rural). Besar kecilnya kebutuhan air untuk domestik dipengaruhi oleh beberapa faktor. Masing-masing faktor mempunyai pengaruh yang berbeda untuk daerah yang bersangkutan sehingga antara daerah yang satu dengan yang lain kebutuhan airnya tidak sama. Faktor-faktor tersebut yaitu : iklim, karakteristik penduduk, masalah lingkungan hidup, industri dan perdagangan, water rate metering, ukuran kota dan kebutuhan konservasi air

Tabel 1. Kebutuhan Air Pulau Bintan

\begin{tabular}{|l|l|l|l|l|l|l|l|}
\hline \multirow{2}{*}{ No } & \multirow{2}{*}{ Kecamatan } & \multicolumn{7}{|c|}{ Kebutuhan Air Dalam $\mathbf{~ m}^{\mathbf{3}} / \mathbf{\text { th}}$ ) } \\
\cline { 3 - 8 } & & \multicolumn{1}{|c|}{ Domestik } & \multicolumn{1}{|c|}{ Industri } & \multicolumn{1}{|c|}{ Ternak } & \multicolumn{1}{c|}{ Perikanan } & Sawah & Total \\
\hline 1 & Bintan Timur & 767485,5 & 1103918 & 157644 & - & & 2.029 .047 \\
\hline 2 & Bintan Utara & 425933,1 & 612643,5 & 94837,6 & 6387500 & & 7.520 .914 \\
\hline 3 & Gunung Kijang & 198830,1 & 285988,5 & 34727,6 & - & & 519.546 \\
\hline 4 & Teluk Bintan & 187902 & 270270 & 50131,4 & 31937500 & & 32.445 .803 \\
\hline 5 & Teluk Sebong & 245477,1 & 353083,5 & 26661,4 & 2555000 & & 3.180 .222 \\
\hline 6 & Bukit Bestari & 4264295 & 1235271 & 13278,4 & & 5.512 .844 \\
\hline 7 & Tanjungpinag Barat & 4044565 & 1171620 & 0 & 52888,5 & 31536 & 5.300 .609 \\
\hline 8 & Tanjungpinang Kota & 1512268 & 438070,1 & 21595,2 & 33726 & & 2.005 .659 \\
\hline 9 & Tanjungpinang Timur & 3518965 & 1019365 & 45904 & 0 & & 4.584 .234 \\
\hline
\end{tabular}

Sumber : BPS Kepri Tahun 2009 dan Hasil Perhitungan 
Kebutuhan air untuk industri merupakan volume air yang dibutuhkan selama proses produksi dalam satu satuan waktu dengan persyaratan-persyaratan tertentu. Besar kecilnya kebutuhan air untuk industri ini disebabkan oleh beberapa faktor diantaranya jenis industri dan jumlah industri. Pulau Bintan yang mencakup dua kabupaten yaitu Kabupaten Bintan dan Kotamadya Tanjungpinang mempunyai jenis industri yang cukup beragam. Perkembangan jumlah industri dan penyerapan tenaga kerja di Kota Tanjugpinang dari tahun ke tahun selalu meningkat.

Prosentase penyerapan tenaga kerja untuk sektor industri di Kabupaten Bintan menempati urutan pertama yaitu sebesar 21,16\% dari total tenaga kerja yang ada dibandingkan dengan sektor usaha yang lainnya (BPS Kepri, 2009). Hal ini menunjukkan bahwa sektor industri merupakan salah satu yang terpenting dalam mempengaruhi ketersediaan dan kebutuhan air Kabupaten Bintan. Kebutuhan air untuk industri di Pulau Bintan sebagian besar termasuk dalam kategori rendah. Terutama di kota Tanjungpinang sebagian besar membutuhkan air dalam jumlah yang tinggi seperti Kecamatan Bukit Bestari sebesar 1.235.270,5 $\mathrm{m}^{3} /$ th. Tingginya kebutuhan air di kecamatan tersebut dikarenakan jumlah karyawannya banyak sehingga kebutuhan air untuk kantor juga tinggi.

Hasil perhitungan kebutuhan air untuk peternakan di Pulau Bintan menunjukkan kebutuhan air paling tinggi adalah Kecamatan Bintan Timur sebesar $157.644 \mathrm{~m}^{3} /$ th dan paling rendah adalah Kecamatan Tanjungpinang Barat. Jumlah ternak yang ada di Kecamatan Bintan Timur lebih banyak dibandingkan dengan kecamatan yang lainya sehingga kebutuhan airnya relatif lebih tinggi. Meninjau kebutuhan air tiap jenis ternak, maka di Pulau Bintan yang paling tinggi adalah kebutuhan air untuk unggas karena hewan ini mendominasi di semua daerah. Adapun kebutuhan air untuk ternak sapi, kuda dan kerbau paling rendah di Pulau Bintan. 




Gambar 1. Peta Kebutuhan Air Pula Bintan

Berdasarkan data yang tersedia hanya ada beberapa kecamatan yang mempunyai kolam ikan. Hasil perhitungan menunjukkan bahwa Kecamatan Teluk Bintan mempunyai kebutuhan air yang paling tinggi. Adapun besar kebutuhan airnya adalah $31.937 .500 \mathrm{~m}^{3} / \mathrm{th}$. Berbeda dengan Kecamatan Bintan Utara yang mempunyai kebutuhan air paling rendah sebesar $2.555 .000 \mathrm{~m}^{3} /$ th.

Berdasarkan data yang ada luas sawah yang ada di Pulau Bintan yaitu 55 Ha yang tersebar di sejumlah Kabupaten Bintan seluas 54 Ha dan Kota Tanjungpinang seluas 1 Ha. Kabupaten Bintan memiliki kebutuhan air untuk sawah sebesar $1702944 \mathrm{~m}^{3} / \mathrm{th}$. Adapun kebutuhan air untuk sawah di Kota Tanjugpinang sebesar $31536 \mathrm{~m}^{3} /$ th. Semakin luas sawah, maka air yang dibutuhkan untuk irigasi juga semakin tinggi. Dan begitu juga sebaliknya, semakin kecil luas sawah kebutuhan airnya relatif rendah.

Kebutuhan air untuk penduduk perlu disesuaikan dengan ketersediaan air yang ada. Hal ini dikarenakan ketersediaan air di permukaan bumi tergantung pada berbagai faktor seperti kondisi fisik dan sosial ekonomi (Tambunan, Rudi P. 2005). Ketersediaan air permukaan berasal dari tiga sumber yaitu : 1) Air yang mengalir di permukaan berupa sungai, 2) Air yang tertampung dalam kolam, waduk, danau, atau rawa dan 3) Air di dalam tanah berupa airtanah. Prediksi ketersediaan air di suatu wilayah diperlukan untuk mengetahui apakah air yang tersedia masih mampu 
mencukupi untuk memenuhi kebutuhan sehari-hari atau tidak agar tidak terjadi krisis air di masa mendatang.

Berdasarkan data yang ada di Pulau Bintan maka untuk menghitung ketersediaan air ditentukan dengan menggunakan metode koefisien limpasan berdasarkan informasi penggunaan lahan serta data curah hujan tahunan (Tjasyono H.K., B. 2004). Berdasarkan hasil perhitungan, ketersediaan air di Kabupaten Bintan sebesar 2.194.614.575 $\mathrm{m}^{3} /$ th dan ketersediaan air di Kota Tanjungpinang sebesar 237.205.048 $\mathrm{m}^{3} /$ th. Jadi, total ketersediaan air di Pulau Bintan $2.431 .819 .623 \mathrm{~m}^{3} /$ th.

Tabel 2. Ketersediaan Air Pulau Bintan

\begin{tabular}{|l|l|l|l|l|l|l|}
\hline No & \multicolumn{1}{|c|}{ Kecamatan } & $\begin{array}{c}\text { Luas } \\
(\mathrm{Ha})\end{array}$ & $\%$ Aliran & Ro (mm/th) & $\begin{array}{c}\text { Aliran Mantap } \\
(\mathrm{mm} / \mathrm{th})\end{array}$ & $\begin{array}{c}\text { Ketersediaan Air } \\
\left(\mathrm{m}^{3} / \mathrm{th}\right)\end{array}$ \\
\hline 1 & Bintan Timur & 46.100 & 0,3 & 1914,123 & 574,2369602 & 264.723 .239 \\
\hline 2 & Bintan Utara & 21.925 & 0,3 & 1914,123 & 574,2369602 & 125.901 .454 \\
\hline 3 & Gunung Kijang & 50.312 & 0,3 & 1914,123 & 574,2369602 & 288.910 .099 \\
\hline 4 & Teluk Bintan & 18.500 & 0,3 & 1914,123 & 574,2369602 & 106.233 .838 \\
\hline 5 & Teluk Sebong & 40.800 & 0,3 & 1914,123 & 574,2369602 & 234.288 .680 \\
\hline 6 & Bukit Bestari & 6.900 & 0,3 & 1914,123 & 574,2369602 & 39.622 .350 \\
\hline 7 & Tanjungpinag Barat & 3.450 & 0,3 & 1914,123 & 574,2369602 & 19.811 .175 \\
\hline 8 & Tanjungpinang Kota & 5.250 & 0,3 & 1914,123 & 574,2369602 & 30.147 .440 \\
\hline 9 & Tanjungpinang Timur & 8.350 & 0,3 & 1914,123 & 574,2369602 & 47.948 .786 \\
\hline
\end{tabular}

Sumber : BPS Kepri Tahun 2009 dan hasil perhitungan

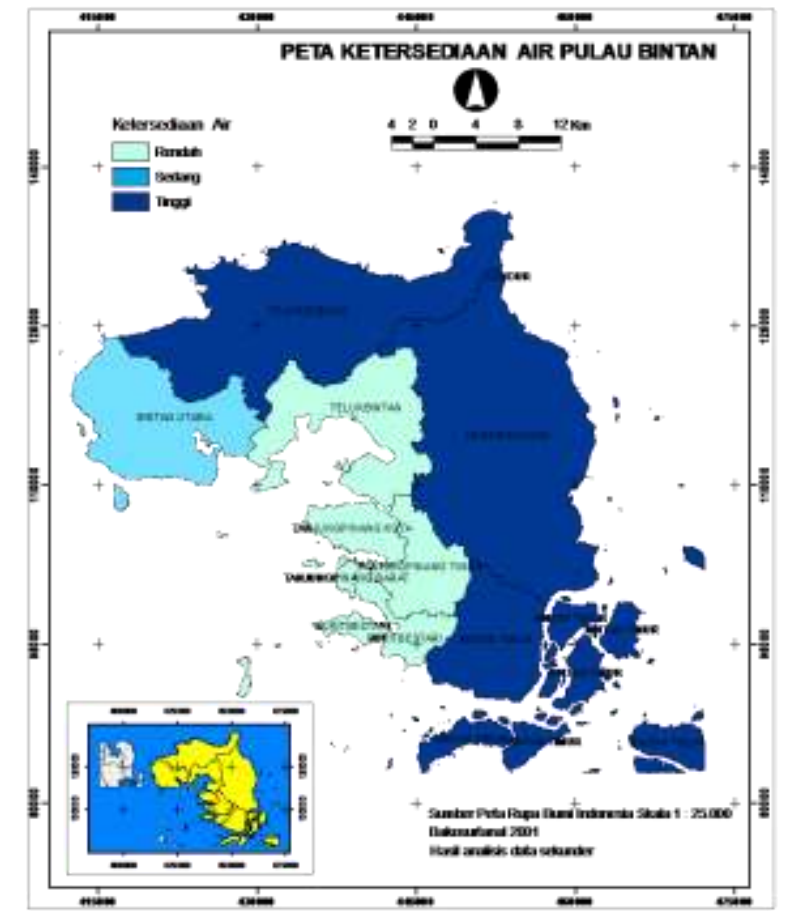

Gambar 2. Peta Ketersediaan Air Pulau Bintan 
Ketersediaan air bagi penduduk menunjukkan indikator daya dukung air bagi lingkungan hidup terutama bagi penduduk dan segala aktivitas kehidupannya. Daya dukung air tersebut meliputi aspek pemenuhan kebutuhan air dan ketersediaannya. Adapun kebutuhan air Pulau Bintan secara keseluruhan mencapai $67.726 .595 \mathrm{~m}^{3} /$ th di mana kebutuhan terbesar dari sektor perikanan.

Jumlah kebutuhan air ini kemudian dibandingkan dengan penduduk yang mendiami Pulau Bintan sehingga diperoleh kebutuhan air tiap orang 221,75 $\mathrm{m}^{3} /$ th/kapita. Sedangkan ketersediaan air Pulau Bintan mencapai 2.431.819.623 $\mathrm{m}^{3} /$ th dan setelah dibandingkan dengan luas Pulau diperoleh ketersediaan air sebesar 11.704,55 $\mathrm{m}^{3} / \mathrm{th} / \mathrm{km}^{2}$. Berdasarkan ketersediaan dan kebutuhan airnya, maka Pulau Bintan mengalami surplus sumberdaya air karena besarnya ketersediaan jauh lebih banyak daripada kebutuhan.

Tabel 3. Daya Dukung Air Pulau Bintan

\begin{tabular}{|c|c|c|c|c|c|c|c|c|}
\hline \multirow{2}{*}{ No } & \multirow{2}{*}{ Kecamatan } & \multirow{2}{*}{$\begin{array}{l}\text { Luas } \\
\text { (Ha) }\end{array}$} & \multirow{2}{*}{$\begin{array}{c}\text { Jumlah } \\
\text { Penduduk }\end{array}$} & \multirow{2}{*}{$\begin{array}{c}\text { Ketersediaan } \\
\text { Air }\left(\mathbf{m}^{3} / \mathrm{th}\right)\end{array}$} & \multirow{2}{*}{$\begin{array}{c}\text { Kebutuhan } \\
\text { Air Total } \\
\left(\mathbf{m}^{3} / \mathbf{t h}\right) \\
\end{array}$} & \multirow{2}{*}{$\begin{array}{c}\mathbf{Y a} \\
\left(\mathbf{m}^{3} / \mathbf{t h} / \mathbf{k m}^{2}\right) \\
\end{array}$} & \multirow{2}{*}{$\begin{array}{c}\text { Za } \\
\left(\mathbf{m}^{3} / \text { th } / \text { kapita }\right)\end{array}$} & \multirow{2}{*}{$\begin{array}{c}\text { DDA } \\
(\text { kapita/km²) } \\
\end{array}$} \\
\hline & & & & & & & & \\
\hline 1 & Bintan Timur & 46.100 & 35.045 & 264.723 .239 & 2.029 .047 & 574.237 & 58 & 9.918 \\
\hline 2 & Bintan Utara & 21.925 & 19.449 & 125.901 .454 & 7.520 .914 & 273.105 & 387 & 706 \\
\hline 3 & $\begin{array}{l}\text { Gunung } \\
\text { Kijang }\end{array}$ & 50.312 & 9.079 & 288.910 .099 & 519.546 & 626.703 & 57 & 10.952 \\
\hline 4 & Teluk Bintan & 18.500 & 8.580 & 106.233 .838 & 32.445 .803 & 230.442 & 3.782 & 61 \\
\hline 5 & Teluk Sebong & 40.800 & 11.209 & 234.288 .680 & 3.180 .222 & 508.218 & 284 & 1.791 \\
\hline 6 & Bukit Bestari & 6.900 & 58415 & 39.622 .350 & 5.512 .844 & 85.949 & 94 & 911 \\
\hline 7 & $\begin{array}{l}\text { Tanjungpinag } \\
\text { Barat }\end{array}$ & 3.450 & 55405 & 19.811 .175 & 5.300 .609 & 42.974 & 96 & 449 \\
\hline 8 & $\begin{array}{l}\text { Tanjungpinang } \\
\text { Kota }\end{array}$ & 5.250 & 20716 & 30.147 .440 & 2.005 .659 & 65.396 & 97 & 675 \\
\hline 9 & $\begin{array}{l}\text { Tanjungpinang } \\
\text { Timur } \\
\end{array}$ & 8.350 & 48205 & 47.948 .786 & 4.584 .234 & 104.010 & 95 & 1.094 \\
\hline
\end{tabular}

Sumber : BPS Kepri Tahun 2009 dan hasil perhitungan

Meninjau daya dukung air tersebut, perlu dilakukan pengelolaan sumberdaya air agar ketersediaan air dapat dimanfaatkan dengan sebaik-baiknya dan sesuai dengan peruntukanya. Hal ini disebabkan suatu daerah ada yang mempunyai daya dukung air kecil tetapi di daerah lain dijumpai daya dukung air yang besar. 


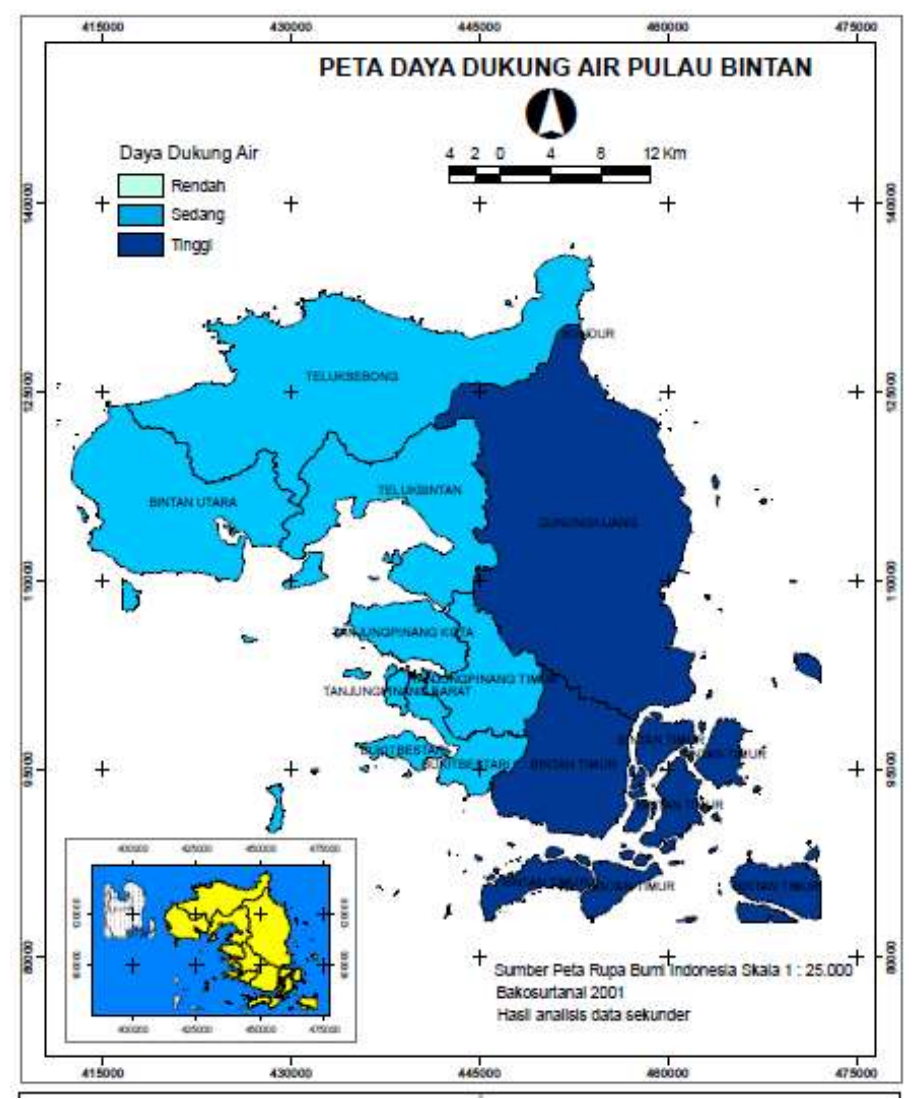

Gambar 3. Peta Daya Dukung Air Pulau Bintan

\section{KESIMPULAN}

Berdasarkan hasil penelitian dapat diambil kesimpulan bahwa Pulau Bintan secara keseluruhan mencapai $67.726 .595 \mathrm{~m}^{3} /$ th di mana kebutuhan terbesar dari sektor perikanan. Perbandingan antara jumlah kebutuhan air dengan penduduk yang mendiami Pulau Bintan sehingga diperoleh kebutuhan air tiap orang 221,75 $\mathrm{m}^{3} /$ th/kapita. Sedangkan ketersediaan air Pulau Bintan mencapai 2.431.819.623 $\mathrm{m}^{3} /$ th dan setelah dibandingkan dengan luas Pulau diperoleh ketersediaan air sebesar 11.704,55 $\mathrm{m}^{3} / \mathrm{th} / \mathrm{km}^{2}$. Berdasarkan ketersediaan dan kebutuhan airnya, maka Pulau Bintan mengalami surplus sumberdaya air karena besarnya ketersediaan jauh lebih banyak daripada kebutuhan.

\section{DAFTAR PUSTAKA}

Badan Pusat Stastistik. 2009.Provinsi Kepulauan Riau Dalam Angka. Badan Pusat Statistik. Kepri. Haryanto TE, Fathurrazie S, Rudy S, Zaenal K. 2013. Actual Water Availability and Water Needs in Irrigation Area of Riam Kanan in South Kalimantan Province. Academic Research International. Vol. 4 No. 6 November 2013 
Mock, F.J., 1973. Land Capability Appraisal Indonesia Water Availability Appraisal. Food and Agriculture Organization of The United Nations. Bogor.

Notodihardjo, M. 1982. Pengelolaan Sumberdaya Air untuk Pengembangan Lingkungan Hidup. Buletin Asosiasi Sumberdaya Air Indonesia. CV. Sarajaya. Jakarta.

Seyhan, E. 1977. Dasar-Dasar Hidrologi. Gadjah Mada University Press. Yogyakarta.

Soewarno. 2000. Hidrologi Operasional Jilid Kesatu. PT Citra Aditya. Bandung.

Tambunan, Rudi P. 2005. Keberlanjutan Ekologis : Ketersediaan Sumber Daya Air. Bunga Rampai Pembangunan Kota Indonesia Dalam Abad 21. Yayasan Sugianto Soegijoko dan URDI. Jakarta.

Tjasyono H.K., B. 2004. Klimatologi. Penerbit ITB. Bandung 